\title{
STOLETÍ ARCHEOLOGICKÉHO VÝZKUMU OSTROVSKÉHO KLÁŠTERA (K. Ú. DAVLE)
}

\section{PETR SOMMER}

\begin{abstract}
Abstrakt: Archeologický zájem o Ostrovský klášter (druhou nejstarši mužskou benediktinskou lokalitu $v$ Čechách založenou okolo roku 1000) trvá vice než jedno století a jeho podoba svým způsobem odráži vývoj české archeologie a archeologie středověku, stejně jako vývoj českých archeologických institucí. První dva terénni výzkumy zde proběhly v letech 1898-1900 a 1907, plně v režii Národního muzea. Se vznikem Československé republiky vstoupil do hry Státní archeologický ústav (a jeho nástupnické organizace), který zahájil v roce 1925 výzkum, jenž sledoval nejenom poznání kláštera a jeho hmotné kultury, ale také jeho památkovou ochranu a prezentaci. Výzkumné kampaně, které pak následovaly (1933-1934, 1947, 1962-1964, 1975-1983), vesměs v režii Archeologického ústavu, rozšiřují svủj záběr od poznání architektonické podoby klášterního komplexu k jeho zasazeni do středovékého sídelního a kulturního kontextu. Výsledkem těchto výzkumů je znalost podoby klášterních staveb prvni dřevěné fáze, stejně jako navazujících etap románské a gotické výstavby. Rozsáhlá kolekce architektonických detaili̊, náhrobních desek, terakotových dlaždic a obkládacích desek i dalšich movitých archeologických nálezů je významná jak pro charakteristiku a dataci zkoumaných objektů, tak pro rozšiřeni našich znalosti o středověké hmotné kultuře a její chronologii.
\end{abstract}

Klíčová slova: benediktinský klášter - archeologie středověku - česká dřevěná, románská a gotická architektura - terakotové architektonické prvky-památková péče.

\section{A century of archaeological research into the Ostrov Monastery (Davle cadastral zone)}

\begin{abstract}
The archaeological interest in the Ostrov Monastery (the second oldest Benedictine male monastery in Bohemia established around 1000) has endured for over a century, and its form in a way mirrors the development of Czech archaeology and archaeology of the Middle Ages, as well as the development of Czech archaeological institutions. The first two field surveys on the site took place in 1898-1900 and in 1907, and were organised by the National Museum. With the establishment of the Czechoslovak Republic (1918) the research was joined by the State Archaeological Institute (and the organisations superseding it) which in 1925 launched research that centred not only on the study of the monastery and its material culture but also on its heritage protection and presentation. Research campaigns that followed (1933-1934, 1947, 1962-1964, 1975-1983), organised mainly by the Archaeological Institute, expanded their focus from the study of the architectural form of the monastery complex to its placement in the medieval settlement and cultural context. The research brought information about the form of the monastery buildings of the first, wooden phase, as well as the following phases of Romanesque and Gothic construction. A vast collection of architectural details, tombstones, terracotta floor tiles and lining panels and other moveable archaeological finds is important for the characteristics and dating of the investigated features, as well as for the expanding of our knowledge about medieval material culture and its chronology.
\end{abstract}

Key words: Benedictine monastery - archaeology of the Middle Ages - Czech wooden, Romanesque and Gothic architecture - terracotta architectural elements - heritage care.

\section{Klášter na Ostrově u Davle a začátky české archeologie}

Na vltavském ostrově před soutokem Vltavy se Sázavou založil okolo roku 1000 kníže Boleslav III. (z odkazu svého otce) klášter nazvaný podle místa svého vzniku Insula. Byl to druhý mužský klášter v Čechách, ale zatímco ten první byl založen v Břevnově u Prahy panovníkem a snad i s pomocí biskupa, vznikl klášter na Ostrově jako důsledek snahy samotného panovníka přivést do země větev reformního mnišství tzv. lotrinské orientace respektující jeho vládu. První skupina benediktinů přišla na Ostrov z bavorského Niederaltaichu, z kláštera, který byl krátce předtím reformován svatoemmeramským konventem v Řezně podle lotrinských principů (Břicháček-Richter-Sommer 2003, 13-17). 
Prameny k začátkům Ostrova hovoří zejména o rodící se klášterní doméně. O tom, jak vznikala a rozrůstala se jeho architektura, však víme téměř jenom díky archeologii. Archeologický a uměleckohistorický zájem o klášter trval již od konce 18. století a jednotlivé fáze jeho poznávání svým způsobem charakterizují vývoj archeologie jako součásti věd o středověku. Onen zájem probudil nález korpusu Ukřižovaného, který z ruin kláštera vyplavila v roce 1799 povodeň. Předmět zhotovený v první polovině 13. století $\mathrm{v}$ Limoges upozornil na skutečnost, že klášteřiště patří mezi významné památky českého středověku a skrývá řadu významných pramenů dokumentujících mimořádné stránky jeho kultury nebo naopak všední dny jeho života (obr. 1). Ve sbírkách Národního muzea v Praze jsou ale i další důkazy trvalého zájmu o Ostrov. Např́iklad ve sbírce lapidária je uložena známá opuková deska s hlavou muže (mnicha?) ze třetí čtvrtiny 12. století, kterou muzeu věnoval v roce 1863 majitel pozemku na Ostrově Čeněk Lichtblau (Stehlíková 2014, 121).

\section{Archeologické výzkumy na Ostrově u Davle}

První rozsáhlejší výzkum v místech zaniklého kláštera proběhl v letech 1898-1900 pod vedením Bohumila Matějky, a to s podporou Archeologické komise České akademie císaře Františka Josefa pro vědy, slovesnost a umění (Almanach X; Almanach XI; Lehner 1905, 196-197). Soustředil se na klášterní jádro a jeho výsledkem byla přibližná znalost jeho stavební dispozice. Zkoumaný kostel byl trojlodní bazilika s dvojvěžovým západním průčelím, arkády byly střídavě podpírány sloupy a pilíríi a boční lodi byly průchody spojeny s chórovými kaplemi doprovázejícími po bocích chór. Ten - stejně jako chórové kaple - uzavíraly apsidy v jedné rovině. K jižní straně chóru byla připojena jednolodní kaple s apsidou. Severně od baziliky byl odkryt půdorys ambitu, jehož západní křídlo bylo otevřeno do rajského dvora čtyřmi sdruženými trojnásobnými románskými okny, vždy se dvěma sloupky. V jižní části ostrova bylo zaznamenáno pokračování zděné zástavby. Vedením výzkumu byl pověřen Bohumil Matějka, absolvent Filozofické fakulty UK v Praze, jenž vystudoval dějiny umění. Do roku 1892 byl kustodem archeologické a historické sbírky Národního muzea, v roce 1900 se habilitoval pro dějiny umění na Akademii výtvarných umění a na České technice, roku 1904 byl jmenován mimořádným profesorem dějin umění na Karlově univerzitě (Vavroušek 1938, 274).

Následující výzkumy pokračovaly $\mathrm{v}$ jádře kláštera, zcela $\mathrm{v}$ souladu $\mathrm{s}$ dobovým názorem, že archeologie a její metoda jsou vlastně nástrojem dějin umění, kterým pomáhá pochopit a interpretovat vývoj památky jako uměleckého i funkčního artefaktu. Takový byl zřejmě i výzkum Václava Fabiána v roce 1907. I on byl absolventem studia dějin umění a historie, od roku 1904 byl asistentem a od roku 1909 adjunktem sbírek historické archeologie Národního muzea. Pracoval zde pod vedením prof. Jana Kouly a spolupracoval s prof. J. L. Píčem, posléze řídil etnografický sektor Národního muzea (Biografický slovník českých zemí). Ačkoliv je vysoce hodnocena jeho zásluha o budování rozsáhlého fotografického etnografického archivu Národního muzea, obrysy jeho práce na Ostrově u Davle jenom tušíme díky stručné zprávě Rudolfa Hlubinky $(1933,3)$, který ř́iká, že byly odkryty apsidy románské baziliky, románská kaple u jižní strany chóru, kvadratura a „,některé jiné stavby“. Zatímco Matějkův výzkum přinesl nálezy deseti opatských hrobů, některých s náhrobními deskami, a hrobu Sudků z Ledče, Fabián nalezl hrob opata Jana Podnavce v jižní chórové kapli (možná spíš pokračoval v jeho výzkumu). Ten nebyl za Matějky úplně odkryt, protože „na něm stál dub“. Hlubinka konstatuje, že všechna dokumentace k výzkumům let 1898-1899 a 1907 se ztratila (,... plány i poznámky ... byly-li vi̊bec jaké pořizeny.“). Přesto alespoň jeden autentický pramen existuje. Jde o rukou provedený plánek výsledků Matějkových a Fabiánových výzkumů, dochovaný ve dvou provedeních. Jedno je uloženo v archivu Archeologického ústavu AV ČR, Praha, v. v. i., dodnes v obálce, která nese datum 31. října 1933 a adresu Josefa Lišky, tehdejšího davelského starosty. Jak se dostalo do archivu ARÚ, se můžeme jenom domýšlet. Určité vodítko poskytuje opět stručný Hlubinkův text (1933, 4), který se zmiňuje o tom, že 12. ř́jina 1933 přišel na výzkum kláštera (o něm viz dále) davelský starosta Josef Liška a přinesl a zapůjčil arch papíru s tužkou nakresleným půdorysem základů ostrovského kostela, v němž 


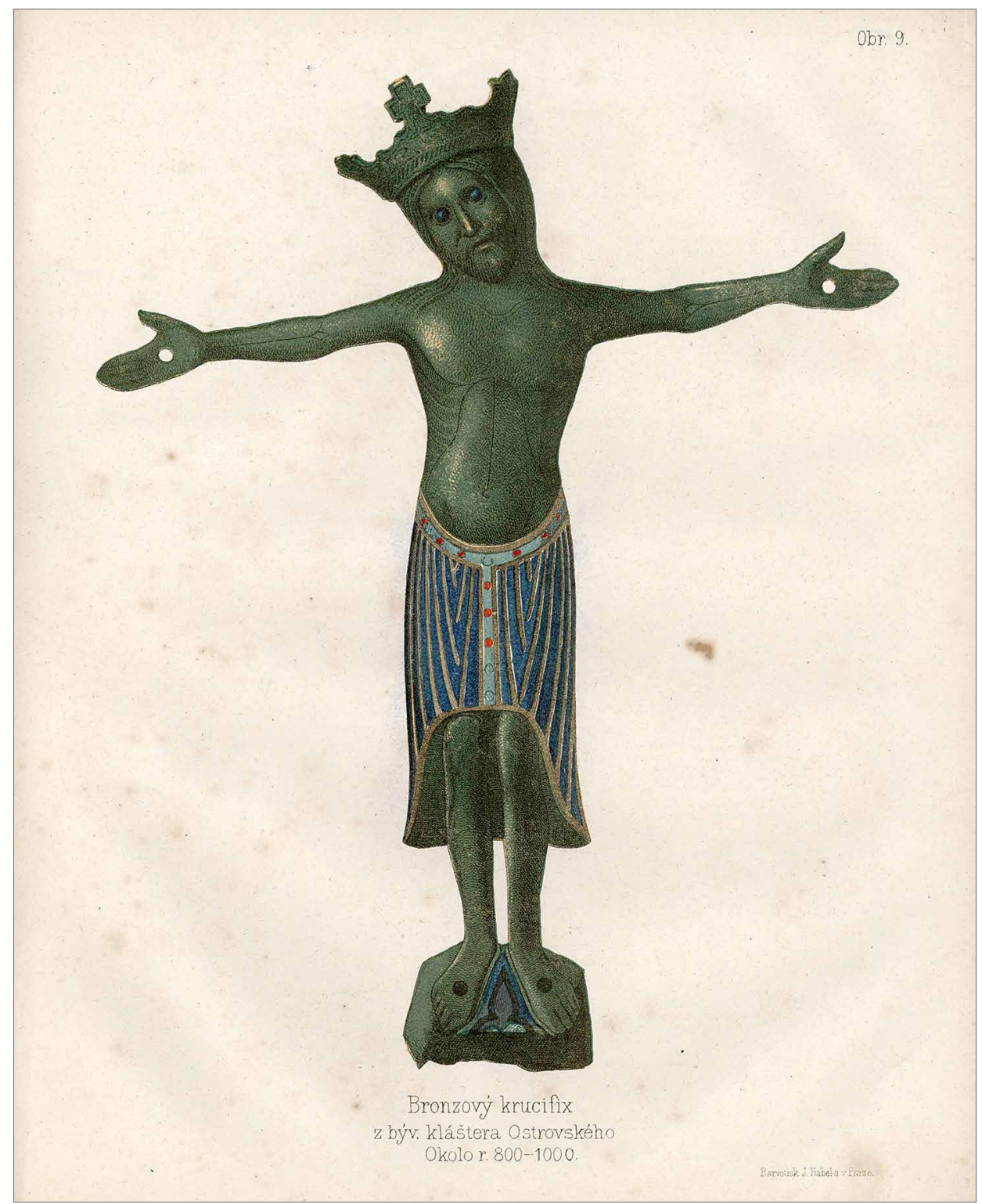

Obr. 1. Novověkou pozornost na sebe Ostrovský klášter přivábil nálezem měděného litého limogeského křižku (Národní muzeum v Praze, inv. č. H2-1.958), který po velké povodni učinil arcibiskupský notář okresu Př́ibram, sekretář a děkan mníšecký Jan Křtitel Cippelius 18. května 1799. V roce 1818 nálezce věnoval křížek Národnímu muzeu a ten začal žít vlastním životem. Jeho významnou etapu zahájil článek Jana Erazima Wocela (1855), od roku 1850 prvního profesora archeologie na univerzitě, a to i proto, že jej doprovázela krásná litografie Josefa Vojtěcha Hellicha, uznávaného malíře a amatérského archeologa. V obrozenecké společnosti způsobil nález senzaci, díky níž vzniklo množství kopií. Mezi nimi byla dokonce načas ztracena orientace, takže za originál byla považována kopie chovaná na hradu Buchlov (Stehlíková 2014, 153).

Abb. 1. Neuzeitliche Aufmerksamkeit hat Kloster Ostrov durch den Fund eines kleinen kupfernen Limogeser Gusskreuzes auf sich gezogen (Nationalmuseum in Prag, Inv-Nr. H2-1.958), den der erzbischöfliche Notar des Bezirks Př́ibram, Sekretär und Dekan von Mníšek Jan Křtitel Cippelius am 18. Mai 1799 gemacht hat. Im Jahr 1818 stiftete der Finder das Kreuz dem Nationalmuseum, das dann ein Eigenleben entwickelte. Dessen wichtige Etappe begann mit einem Artikel von Jan Erazim Wocel (1855), ab 1850 erster Universitätsprofessor für Archäologie, und zwar auch deshalb, weil der Artikel eine schöne Lithographie von Josef Vojtěch Hellich, einem anerkannten Maler und Amateurarchäologen enthielt. In der Gesellschaft der nationalen Wiedergeburt rief der Fund eine Sensation hervor, dank der eine Fülle an Kopien entstand. Bei ihnen hatte man sogar für kurze Zeit die Orientierung verloren, sodass die auf Burg Buchlov aufbewahrte Kopie als Original angesehen wurde (Stehlíková 2014, 153). 
byly červeným inkoustem zakresleny pozice nalezených hrobů a náhrobních desek. Plánek prý vyhotovil Václav Landa a věnoval jej starostovu otci, také starostovi Davle, rovněž jménem Josef Liška. Exemplář Archeologického ústavu je proveden tužkou a jsou do něj červeným inkoustem zaneseny pozice náhrobních kamenů a některých dalších detailů (obr. 2). Jde-li skutečně o Landův dokument (formálně odpovídá Hlubinkovu popisu), snad starosta Liška změnil zapůjčení $\mathrm{v}$ darování a plánek věnoval v obálce od dopisu, který mu byl odeslán 31. ř́inna. Ve věci je malá nesrovnalost: Hlubinka neříká nic o tom, že plánek zobrazuje více než jenom kostel, což může být způsobeno jeho zkratkovitým vyjádřením, když chtěl zdůraznit, že díky plánku lze lokalizovat některé nalezené náhrobní desky.

Druhé provedení plánku publikovala Dana Stehlíková (2003, 78). Nevíme, pro koho bylo pořízeno, ale víme, kdo je zhotovil. V jeho pravém dolním rohu je totiž napsáno: „Kopii tuto pořídil 1. 11. 1933 R. Hlubinka“ (obr. 3). Přes rozdílnou kvalitu provedení jsou oba plánky informačně téměř totožné (pomineme-li různé gramatické odlišnosti) a vyplývá z nich, že oproti výsledkům Matějkova výzkumu je zde zachycen půdorys celého ambitu, jehož vnitřní obvod je šrafovaný, což má nejspíše naznačovat, že jde o zdivo nalezené. Víme, že zdivo východního a severního ambitu bylo známo díky Fabiánovu výzkumu a že cílem jeho práce bylo také detailní poznávání interiéru baziliky včetně kaple jižně od ní. Plánky se shodují s Hlubinkovým popisem výsledků prvních dvou výzkumů Ostrova, přinášejí identický přehled o umístění nalezených náhrobních desek (opravdu jenom díky tomu jsme schopni lokalizovat některé ostrovské náhrobní desky uložené dnes v lapidáriu Národního muzea) a o detailech vybavení interiéru baziliky, jako jsou jednotlivé oltáře, schody vedoucí do chóru, „Stützenwechsel“"v arkádách baziliky nebo hrob opata Jana Podnavce (II.) v jižní chórové kapli. Na první pohled oba plánky obsahují nepřesnost při zakreslení oken v ambitu - jedno okno na každé jeho straně je vynecháno. Již jsme konstatovali, že plánek Archeologického ústavu je pro znaky zmiňované Matějkou a pro souvislost se starostou Liškou nejspíše dílem laboranta Landy.

Václav Landa, vysloužilý K. u. k. ženista, byl osobnost velmi zajímavá a jeho působení v Národním muzeu nebylo zdaleka jenom pozitivní. Stal se však (od roku 1892 při zřízení oddělení historické archeologie) nepostradatelným pomocníkem prof. Kouly a (od roku 1893, po zřízení oddělení prehistorické archeologie) také prof. Píče (Sklenář 2013, 88-90). Oba archeologové jej znali od roku 1891, z doby př́íprav Jubilejní výstavy, při nichž byl Landa zaměstnán. Po Píčově smrti asistoval Václavu Fabiánovi, ale spolupracoval s ním už dříve, třeba právě na ostrovském výzkumu roku 1907.

Ostrovské výzkumy se v prvních dvou etapách jednoznačně spojují s Národním muzeem a s konstituováním jeho dvou archeologických pracovišt'. Existuje ale ještě jeden důležitý prvek, který všem popisovaným skutečnostem dává společného jmenovatele. Když se v roce 1892 stěhovaly sbírky Národního muzea do nové budovy, došlo k definování sbírek pravěké archeologie, historické archeologie a národopisu. A současně se také zjistilo, že nová budova není schopna všechny sbírky pojmout. Logickým důsledkem bylo neuspokojivé uložení zejména lapidária, které bylo zdrojem důležitých exponátů Jubilejní výstavy roku 1891, Národopisné výstavy roku 1895, Výstavy architektury a inženýrství v roce 1898 a Jubilejní výstavy Obchodní a živnostenské komory. Všechny proběhly na pražském Výstavišti, přičemž třetí z nich se stala konečně impulzem ke stabilizaci situace lapidária NM. Vůdčím duchem přitom byl Bohumil Matějka. Při výstavě roku 1898 byla historická expozice (založená na sbírce lapidária NM) umístěna ve Wiehlově pavilonu výstaviště z roku 1891, v němž lapidárium už zůstalo. Jeho kolekce se stále rozrůstala, $v$ té době byla významně obohacována Matějkovými nálezy z Ostrova u Davle. $\mathrm{V}$ roce 1905 došlo také konečně k institucionalizaci lapidária. Na instalaci jeho první expozice (v níž se opět významně uplatňovaly ostrovské nálezy) se podíleli Jan Koula a Václav Fabián. Expozice byla dokončena v roce 1910 (Fabian 1910-1912; Drobná 1958, 13-26). Je dosti pravděpodobné, že i Fabiánův výzkum měl v této souvislosti úlohu akce, která měla dosavadní zisky lapidária doplnit. Podle citovaného Hlubinkova svědectví ale výzkum podněcoval jako cennou vědeckou akci i prezident České akademie věd a umění Josef Hlávka a její jednatel J. L. Píč. 


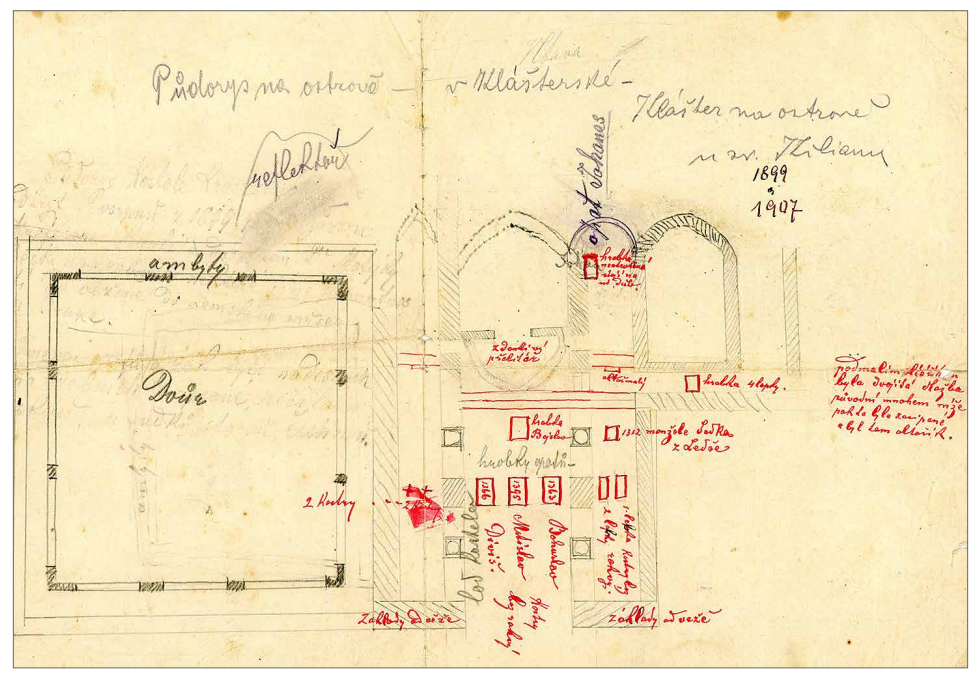

Obr. 2. Plánek výzkumů na Ostrově u Davle prováděných v letech 1898-1899 Bohumilem Matějkou a v roce 1907 Václavem Fabiánem. Pravděpodobně jde o plánek, který vyhotovil laborant Národního muzea Václav Landa, o němž referuje Rudolf Hlubinka k roku 1933 (viz text). Plánek asi věnoval StAÚ davelský starosta Josef Liška jako dědictví po svém otci. Plánek je kreslen tužkou a jsou do něj vloženy detaily, na něž chtěl autor upozornit, a proto je zakresloval červeným inkoustem. $K$ jednotlivým situacím jsou vepsány vysvětlující poznámky. První verze neúplného plánku byla vygumována. Projevuje se liniemi ledabyle načrtnutého ambitu nepatrně se rýsujícího pod definitivní kresbou křižové chodby s vysvětlením, že jde o „ambyty“. Přes tento obrys je tužkou vepsaný text, který je téměř nečitelný, ale pokud lze posoudit, byl doslova přepsán R. Hlubinkou na kopii tohoto plánku (viz obr. 3): „P Pidorys kostela klášterského odkryt v srpnu r. 1899 pod dozorem profesora Kouly a dozorem Dr. Matějky. Desky na hrobech a některé jiné památnosti odvezeny do zemského muzea v Praze. Jména opatů a rok byly na deskách náhrobních napsány řeči latinskou, u Sudků starou češtinou. " Další komentář $\mathrm{k}$ detailům situace není třeba v této souvislosti uvádět. Význam má poznámka vepsaná $\mathrm{k}$ hrobu Jana Podnavce (II.) v jižní chórové kapli, která ŕíká „hrobka neotevřená stojí na ní dub“. Podle Bohumila Matějky byla Podnavcova hrobka zkoumána až v době Fabiánova výzkumu, ale víme, že již Matějka získal část náhrobní desky, která jej kryla. Zjevně mu překážel onen dub z plánku. Plánek má ale zachycovat také výsledky Fabiánova výzkumu, kdy byl výzkum hrobu dokončen (popravdě ale byl dokončen až v 80. letech). Aby byl chaos dokonalý, je informace s dubem napsána přes informaci napsanou tužkou: „Johan“ a dvakrát „opat“. Na těžko čitelný text o výzkumu byl nakreslen definitivní půdorys ambitu opět s popiskou „ambyty“, v prostoru rajského dvora je vysvětlivka „Dvůr" a za linií východního ambitu je slovo „refektář““, což samozřejmě funkěně neodpovídá. Kromě dalších detailů je významné zakreslení náhrobních desek do prostoru hlavní lodi: (nejvýchodněji) opata Bojslava (správně Vojslava, † asi 1317), západně od ní tři desky (zleva) opatů Diviše (1366), Mstislava (správně Zdislava?, † 1395) a Bohuslava († 1363). Ve východní části jižní lodi byl nalezen náhrobek šlechtické rodiny Sudků z Ledče. Náhrobník Jana Podnavce byl vyzdvihován asi třikrát - v době Matějkova, Fabiánova i Guthova výzkumu (srov. Stehlíková 2003, 84-93).

Abb. 2. Planskizze der auf der Insel Ostrov bei Davle in den Jahren 1898-1899 von Bohumil Matějka und im Jahr 1907 von Václav Fabián durchgeführten Grabungen. Wahrscheinlich handelt es sich um eine von Václav Landa, einem Laboranten des Nationalmuseums angefertigte Planskizze, über den Rudolf Hlubinka im Jahr 1933 referiert (siehe Text). Die Planskizze wurde dem Staatlichen Archäologischen Institut wohl von dem Davler Bürgermeister Josef Liška aus dem Nachlass von dessen Vater gestiftet. Die Planskizze wurde mit Bleistift gezeichnet und enthält Details, auf die der Autor aufmerksam machen wollte, weswegen er sie mit roter Tinte koloriert hat. Die jeweiligen Situationen wurden mit erläuternden Anmerkungen versehen. Die erste Version der unvollständigen Planskizze wurde ausradiert. Sie präsentiert sich durch die Linien eines schludrig skizzierten, sich unter der definitiven Zeichnung des Kreuzgangs nur schwach abzeichnenden Ambitus mit der Erläuterung, dass es um „Ambitus“ geht. In diesem Umriss befindet sich ein mit Bleistift geschriebener Text, der fast unleserlich ist, aber - soweit man beurteilen kann von R. Hlubinka wörtwörtlich in die Kopie dieser Planskizze übertragen wurde (siehe Abb. 3): „Grundriss der im August d. J. 1899 unter der Aufsicht von Professor Koula und der Aufsicht von Dr. Matějka freigelegten Klosterkirche. Grabplatten und einige andere Denkwürdigkeiten in das Landesmuseum in Prag gebracht. Die Namen der Äbte und das Jahr waren aufden Grabplatten in lateinischer Sprache geschrieben, bei den Sudeks in Altschechisch." Ein weiterer Kommentar zu den Details der Situation muss in diesem Zusammenhang nicht angeführt werden. Von Bedeutung ist die zum im Südchor der Kapelle befindlichen Grab von Jan Podnavec (II.) eingetragene Bemerkung folgenden Wortlauts, ,, ungeöffnete Grabstätte auf ihr steht eine Eiche“. Laut Bohumil Matějka wurde die Grabstätte von Podnavec erst zur Zeit von Fabiáns Grabung untersucht, jedoch wissen wir, dass bereits Matějka einen Teil der Grabplatte, von der sie bedeckt war, an sich brachte. Offensichtlich stellte jene Eiche aus der Planskizze für ihn ein Hindernis dar. Die Planskizze soll aber auch die Ergebnisse von Fabiáns Grabung erfassen, nachdem die Untersuchung des Grabes beendet war (in Wirklichkeit wurde sie aber erst in den achtziger Jahren beendet). Um das Chaos perfekt zu machen wurde die Information mit der Eiche über folgende, mit Bleistift geschriebene Information geschrieben: „Johan“ und zweimal „Abt“. Auf den schwer leserlichen Text über die Grabung wurde der definitive Grundriss des Ambitus gezeichnet, wieder mit der "Beschriftung „,Kreuzgänge“, im Bereich des Klosterhofes ist die Erläuterung „Hof“, und hinter den Linien des östlichen Kreuzganges das Wort „Refektorium“, was der Funktion selbstverständlich nicht entspricht. Außer weiteren Details ist die Einzeichnung der Grabplatten im Bereich des Hauptschiffes von Bedeutung: (am östlichsten) von Abt Bojslav (richtig Vojslav, $\dagger$ ca. 1317), westlich davon die drei Platten (von links) der Äbte Diviš (1366), Mstislav (richtig Zdislav?, † 1395) und Bohuslav († 1363). Im Ostteil des Südschiffes wurde die Grabstätte der Adelsfamilie Sudek von Ledeč entdeckt. Der Grabstein von Jan Podnavec wurde wohl dreimal gehoben - während Matějkas, Fabiáns und auch Guths Grabung (vgl. Stehlíková 2003, 84-93). 


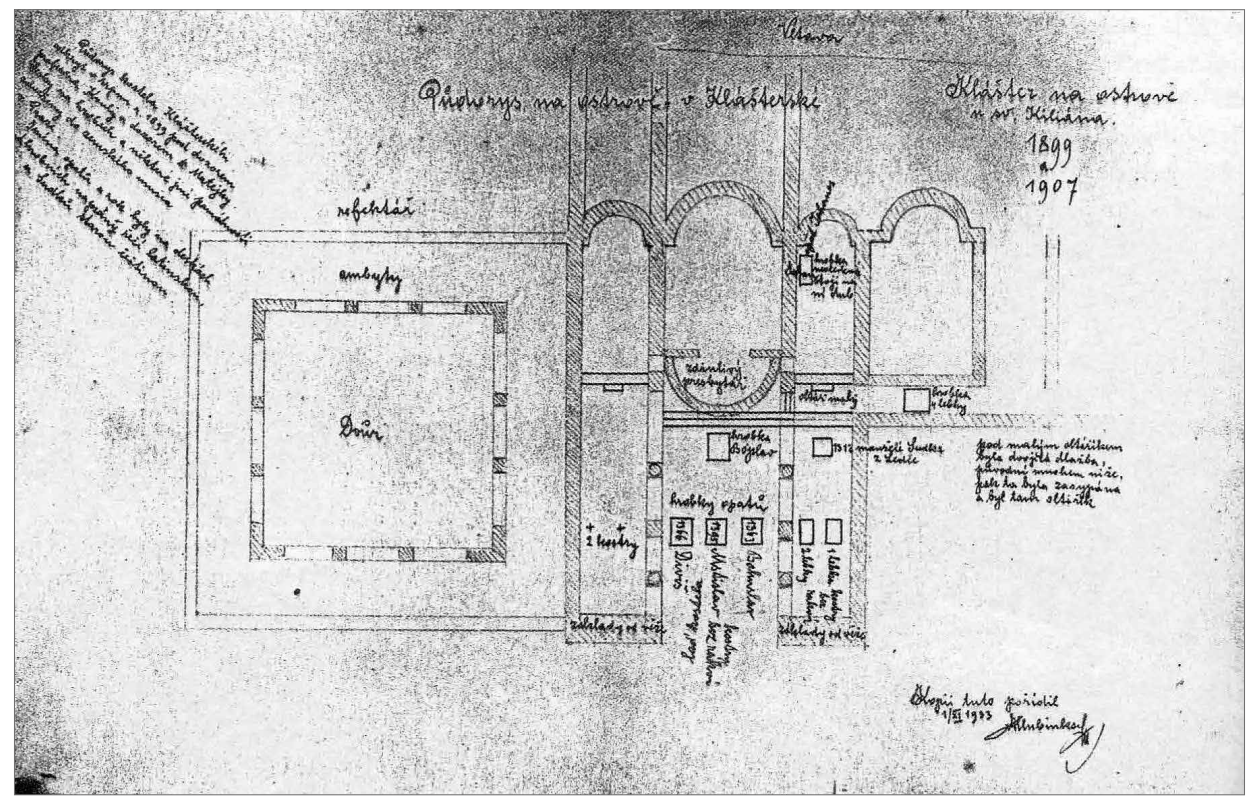

Obr. 3. Kopie plánku Václava Landy (?) - dnes uložena neznámo kde - nese stejný nadpis jako plánek předchozí: „Klášter na ostrově u sv. Kiliána 1899 a 1907.“ „Půdorys na ostrově v Klášterské.“ Odlišná je informace: „Kopii tuto pořídil 1. XI. 1933 R. Hlubinka" († 2. 2. 1951, od roku 1920 velmi aktivní spolupracovník Památkového sboru hlavního města a po roce 1914 pracovník stavebního referátu pražského magistrátu pro Prahu I-VI podílející se na záchraně a poznání řady středověkých pražských památek a mimo jiné i na Ostrově u Davle; Uhlíková 2013).

Abb. 3. Die Kopie der Planskizze von Václav Landa (?) - heutiger Aufbewahrungsort unbekannt - trägt dieselbe Überschrift wie die vorherige Planskizze: „Kloster auf der Insel St. Kilian 1899 und 1907.“ „Grundriss auf der Insel in Klášterská.“ Von ihr

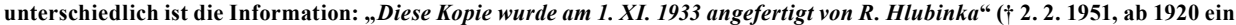
sehr aktiver Mitarbeiter des Denkmalbeirats der Hauptstadt und nach 1914 Mitarbeiter des Baureferats des Prager Magistrats für die Stadtteile Prag I-VI, der an der Rettung und Erkennung von einer Reihe mittelalterlicher Prager Denkmäler, u.a. auch auf der Insel Ostrov bei Davle beteiligt war; Uhlíková 2013).

Další archeologický výzkum zaměřený na Ostrov u Davle proběhl v roce 1925 . V té době již naplno vstoupil do života Státní archeologický ústav (StAÚ) založený v roce 1919. Podnětem k zahájení výzkumu byla jedna z typických pozitivních aktivit Rudolfa Hlubinky. Ten se 19. listopadu 1919 dočetl v Národních listech o projektu na splavnění Vltavy v úseku Vrané-Štěchovice se záměrem využití vodní energie ve Vraném (tedy se záměrem stavby vranské prrehrady; Hlubinka 1933, 3). S pomocí Zemského památkového úřadu se mu podařilo změnit projekt, v jehož původním pojetí by celý Ostrov zmizel pod vodou. Se záchranou Ostrova a jeho prezentací měl souviset výzkum, který měl být zahájen již v létě 1920, ale př́pravy se protáhly až do roku 1925. Jeho provedení velice podporoval ředitel StAÚ Karel Buchtela, vedením pověřil tehdy čtyřiadvacetiletého začínajícího archeologa Jaroslava Böhma. Tento žák Jaroslava Palliardiho a Lubora Niederla, postupně stále významnější představitel československé archeologie a Státního archeologického ústavu, jemuž byl v roce 1939 postaven do čela, provedl řadu významných terénních výzkumů na území celého státu a publikoval řadu fundamentálních prací. On sám v dochované dokumentaci výzkumu roku 1925, uložené v ARÚ Praha v rámci jeho pozůstalosti, charakterizuje ostrovský výzkum jako zjištovací, což dává tušit, že měl být jenom úvodní etapou jiné, daleko větší výzkumné kampaně (obr. 4). Dokumentace sestává z pěti plánů terénní situace a z nálezového deníku, z nějž vyplývá, že šlo o nevelkou akci probíhající od 21. září do 7. října 1925. Je zřejmé, že šlo zejména o orientaci na lokalitě a v předchozích výzkumných výsledcích. V každém případě Böhmovým výzkumem vstoupil do hry Státní archeologický ústav a není jenom shodou okolností, že se to stalo v roce, kdy StAÚ zahájil také fundamentální výzkum 


\section{KLA'STTER OSTROV}

predběžný plán zjištovaciho výzkumu r. 1925.

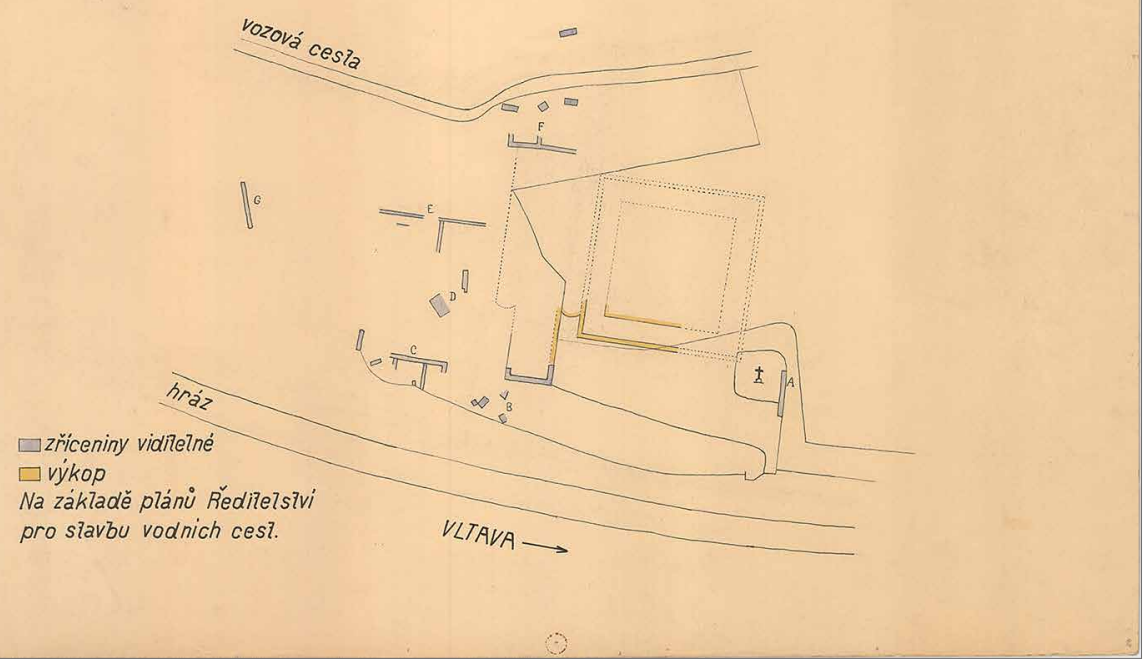

Obr. 4. Celkové zaměření výsledků výzkumu Jaroslava Böhma v roce 1925 a ruin viditelných nad povrchem terénu. Zdroj archiv ARÚ Praha.

Abb. 4. Gesamtvermessung der Grabungsergebnisse von Jaroslav Böhm im Jahr 1925 und der oberhalb der Geländeoberfläche sichtbaren Ruinen. Quelle Archiv des Archäologischen Instituts der Akad. d. Wissenschaften in Prag.

Pražského hradu (Sklenář-Sklenářová 2005, 82-83). Výsledky na Ostrově odpovídají záměru systém sond zejména $\mathrm{v}$ prostoru klauzury měl ověřit spolehlivost znalostí půdorysu budov a prověřit stratigrafickou situaci lokality. Odkryty byly části východního a jižního křídla kvadratury a byla pořízena dokumentace známých částí architektury, zjevně s cílem připravit podklady pro jeden z největších prvorepublikových archeologických výzkumů provedených nejenom Státním archeologickým ústavem, ale jakoukoliv československou institucí vůbec.

Touto akcí se stal rozsáhlý výzkum let 1933 a 1934, který vedl Karel Guth, přednosta historicko-archeologického oddělení Národního muzea. Jako absolvent studia historie a dějin umění na FF UK v Praze (byl žákem Karla Chytila, Josefa Pekaře, Gustava Friedricha a Josefa Šusty) byl v roce 1917 přijat do oddělení historické archeologie NM, které od roku 1921 vedl, a byl také členem řady památkářských institucí a grémií, mimo jiné Archeologické komise ČAVU. Pro výzkum na Ostrově byl tedy plně kvalifikován (Květ 1946) a v době jeho zahájení byl také spolupracovníkem StAÚ. Konzultantem zdejších prací byl architekt, maliřr, restaurátor a památkář František Xaver Margold, v té době pracovník Státního fotoměřického ústavu, v jistém smyslu souputníka StAÚ (Pácal 2007). Výzkum byl mimořádný již jenom rozsahem. Snažil se získat co nejvíce informací o detailech dispozice kláštera a jejího vývoje, aby bylo možné přesně definovat chráněné území a přispět k památkovému zajištění celé lokality. Výsledky tohoto výzkumu jsou zachyceny v dokumentaci, která je uložena v ARÚ Praha a v archivu Národního muzea. Jde především o plánovou dokumentaci (autor Ing. Gustav Varvažovský, spolupracovník Rudolfa Hlubinky, srov. např. Wirth 1948, 4), která se stala podkladem pro sumarizující plán klášterního komplexu s vyznačením románské a gotické části staveb vzniklých od 12. do 15. století (obr. 5). Tento plán je od 30. let minulého století základní informací o podobě svatojanského kláštera, je však stále 


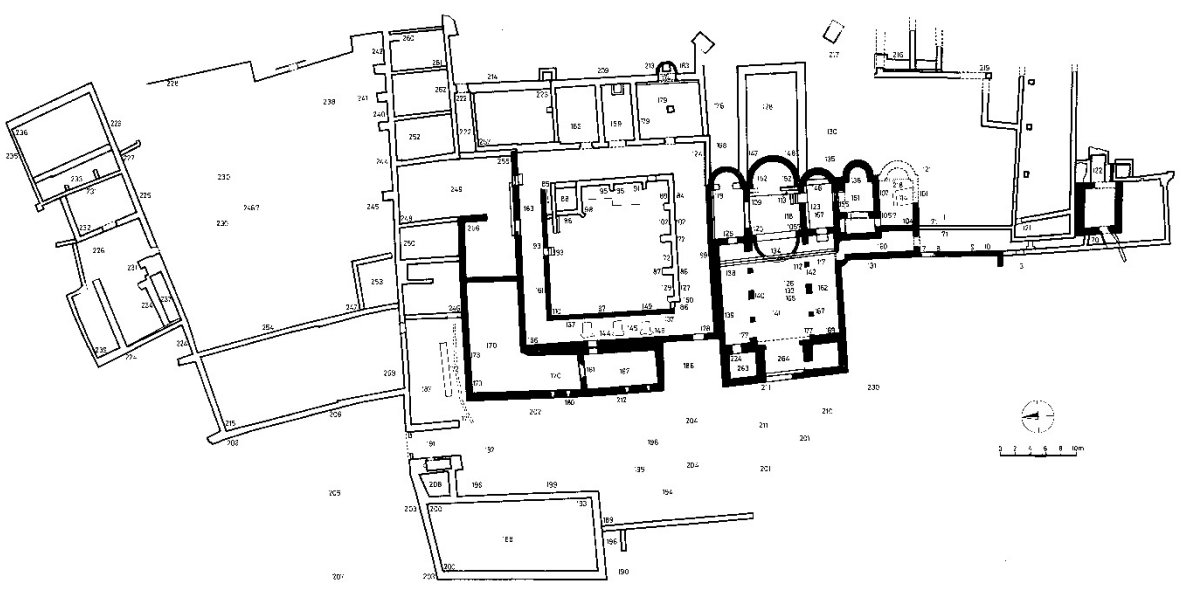

Obr. 5. Plán výsledků výzkumu let 1933-1934 (Karel Guth) s vyznačením nálezových poloh zejména architektonických detailů. Černě jsou zakresleny půdorysy románské baziliky, kř́ídel klauzury a budovy na jižním konci Ostrova. Zdroj archiv ARÚ Praha.

Abb. 5. Plan der Grabungsergebnisse der Jahre 1933-1934 (Karel Guth) mit Kennzeichnung der Fundlagen besonders bzgl. der architektonischen Details. Schwarz eingezeichnet sind die Fundamente der romanischen Basilika, der Klausurflügel und des Gebäudes am Südende von Ostrov. Quelle Archiv des Archäologischen Instituts der Akad. d. Wissenschaften in Prag.

doplňován a zpřesňován, protože výzkum 30. let nebyl veden s analytickou snahou o vyjasnění detailů, ale šlo o postižení celku a jeho základních vývojových etap. Při výzkumu byly vedeny také nálezové deníky (dva sešity), jejichž originály jsou uloženy opět v ARÚ Praha. Zahrnují období od 11. záŕí do 9. prosince 1933 a od 3. července do 8. ř́ijna 1934. Autory zápisů jsou Rudolf Hlubinka (viz výše), Libuše Jansová, tehdy začínající vědecká pracovnice ústavu (Sklenář-Sklenářová 2005, 728-729), a Vojtěch Budínský-Krička/Budaváry, významný slovenský archeolog, v letech 1933-1939 pracovník StAÚ (Filip 1966, 180). Jako dokumentátoři se výzkumu účastnili Antonín Knor, terénní technik StAÚ od roku 1930 (Sklenář-Sklenářová 2005, 295-296), a Václav Landa (viz výše; o technicích výzkumu srov. Stehlíková 2003, 77 a 99). U účasti Václava Landy je však třeba udělat otazník, protože už nemohlo jít o laboranta NM Václava Landu. Ten v roce 1922 zemřel (Sklenář-Sklenářová 2005, 339). Bud’ tedy jde o neuvěřitelnou shodu jmen, nebo je informace o Landovi omylem. Tento zdánlivě nedůležitý detail má význam pro datování plánku Matějkových a Fabiánových výzkumů (viz text u obr. 2). Deníky jsou často velmi podrobné a slovní záznamy doplňují skici zkoumaných poloh, které jsou číslovány (některé skici, které byly $\mathrm{k}$ deníkům původně přiloženy, ale dnes chybějí). Skutečnost, že se čísla poloh promítala do evidence nálezů, byla rozhodující při pozdějším zpracování nalezených architektonických detailů, prováděném Anežkou Merhautovou (viz dále). Deník ze sezony 1934 však vykazuje velmi kolísající úroveň. Dokumentace, kterou doplňuje velká kolekce fotografií, dokazuje, že hlavním cílem výzkumu bylo poznání architektury kláštera, v zásadě odkrývané v zánikové úrovni, eventuálně v první úrovni archeologických objektů, zejména hrobů. Při výzkumu šlo zjevně o čas, takže byla zř́izena úzkokolejka z jižní do severní strany Ostrova, po níž se transportovala vykopaná zemina. V důsledku takového způsobu výkopů nemohly být mnohé detaily objektů patřičně sledovány, především byl rekonstruován půdorys kláštera v románském a gotickém období. Potvrdilo se, že soubor klášterních budov byl na ploše Ostrova (limitován možnostmi terénu) budován podél severojižní osy lokality. Ve středu jeho kompozice vznikl konventní kostel - trojlodní bazilika, jejíž hlavní apsidu nahradil ve 14. století dlouhý pravoúhlý chór. K jižnímu boku trojdílného chóru přiléhala jednolodní kaple se západní emporou, na niž směrem k jihu navazoval prostor snad další sakrální stavby. Podél západního průčelí obou těchto objektů vedla spojovací chodba směřující od 


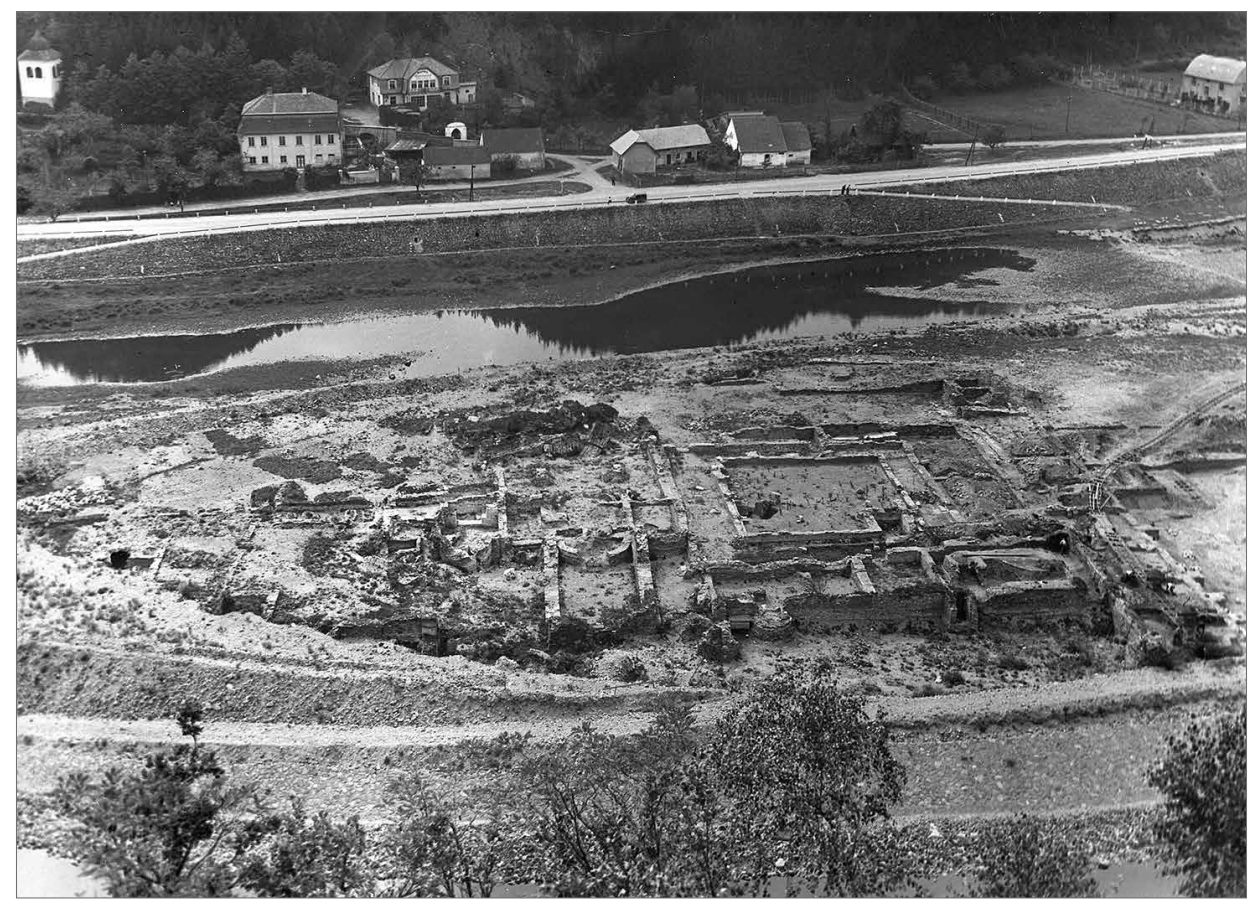

Obr. 6. Celkový pohled na odkryté základy Ostrovského kláštera po výzkumu let 1933-1934. Zdroj archiv ARÚ Praha.

Abb. 6. Gesamtansicht der freigelegten Fundamente des Ostrover Klosters nach der Grabung von 1933-1934. Quelle Archiv des Archäologischen Instituts der Akad. d. Wissenschaften in Prag.

bočního vstupu do jižní lodi baziliky směrem na jih, do prostoru staveb nejasného účelu s velkým halovým objektem s asymetricky umístěnou řadou pilíř̉. Severně od kostela vyrostla klauzura. Z románské stavby kláštera bylo zachyceno jenom její západní a severní křrídlo. Východní křídlo klauzury bylo klasifikováno jako gotická stavba, v odhalených základových partiích kapitulní síně $\mathrm{s}$ malým polygonálním presbytáříkem však byly shledány disproporce mezi průběhem nadzemních a základových zdiv, což by mohlo svědčit o existenci (logického) staršího předchůdce stavby. Jižní rameno ambitu bylo rovněž gotické. Na severní křídlo klauzury atypicky navazoval třetí trakt - hospodářského účelu. Na západní průčelí tohoto traktu navazovala vstupní brána, k jejíž západní straně přiléhala velká obdélná gotická budova. Ještě dále k severu byly odkryty půdorysy objektů, které rovněž patřily k provoznímu zázemí kláštera (obr. 6).

Po ukončení výzkumů v 30 . letech se pohyb na Ostrově opět na delší čas zastavil. Dokončená vranská přehrada opravdu Ostrov nezaplavila a mohly zde probíhat základní konzervační práce spočívající v nadezdívání korun odhalených zdí ochrannými vrstvami zdiva. Některé odkryté objekty (zdiva, hroby) byly překryty dehtovým papírem a zasypány. Nejenom vlastní výzkum, ale i tyto kroky byly velkorysé, Ostrov měl být nejspíše opravdu prezentován veřejnosti, ale jak se ukázalo později, tyto kroky jeho architekturu stejně nemohly ochránit dostatečně.

Přes dosažené výsledky bylo stále zřejmější, že velký soubor disponibilních nálezů a informací neřeší jemněji formulované otázky historie kláštera. Jako první na tuto skutečnost reagoval František Stehlík, mladý historik umění, který si uvědomil, že poznávání historie architektury musí probíhat analytickými nástroji, jež se v následujících letech stabilizovaly v oboru stavebně historického průzkumu. Promyslel systém otázek, které chce řešit, a činil to mikrosondami v klíčových pozicích zejména baziliky (obr. 7). Výsledkem je sumarizující text (Stehlík 1947), v němž autor reviduje následnost jednotlivých fází stavby a všímá si i takových detailů, jako je 
špatná návaznost ochranných nadezdívek na originální zdivo. Na základě svých zjištění přistoupil Stehlík k rekonstrukci románské a gotické podoby jádra kláštera, k nimž lze mít v detailu řadu připomínek, ale $\mathrm{v}$ zásadě odpovídají hmotové rekonstrukci budov i z dnešního hlediska (obr. 8,9).

Také následující výzkum Miroslava Richtera a Ladislava Špačka z let 1962-1964 v tomto způsobu poznávání pokračoval, ale stavěl si složitější otázky vývoje, funkce a datování kláštera $\mathrm{s}$ vědomím výsledků výzkumu klášterního městečka v poloze Sekanka nad klášterem. I tento výzkum analyticky zkoumal strukturu staveb v jádru kláštera a přinesl řadu nových pozorování. Mezi nimi na předním místě je objasnění funkce zděných schrán jižně a severně od románského schodiště vedoucího do hlavní apsidy k oltáři. V jedné z nich byla nalezena in situ ozvučnicová nádoba ležící na boku, obrácená ústím do prostoru chóru. Šlo o jeden z prvních nálezů této technické keramiky u nás (Špaček 1963; podle poznámky v citovaném článku - s. 134 - je zřejmé, že o ozvučnicích věděl i František Stehlík). Dalším významným zjištěním, které ještě šířeji zdůvodnil následující výzkum v 70. letech (viz dále), bylo vyřešení vztahu tzv. první jižní kaple připojené k jižnímu boku jižní chórové kaple baziliky. O této kapli se vyjádřil již Karel Guth (1937), že je pozůstatkem nejstarší fáze kamenného kláštera, která vznikala v 11. století na místě původního dřevěného provizoria. Tuto myšlenku rozvinul Václav Mencl (1959) a ostrovskou první jižní kapli zahrnul do své koncepce české předrománské architektury. Podle něj byla dílem doby okolo roku 1000, tedy doby založení kláštera. Výzkum 60. let ale přinesl zjištění, že stratigrafické vazby kaple na baziliku a zejména skutečnost, že v jejím základu byl použit kámen s omítkou se zbytky fresky (tedy sekundárně použitý kámen), svědčí o tom, že nemůže jít o první zděný objekt na klášteřišti (Špaček 1967). Šlo o krok, který souvisel s vývojem archeologické argumentace a který poukázal na potenciál archeologie schopné účinně argumentovat v diskusi o interpretaci pramenů.

Zatím poslední výzkum ostrovského klášteřiště v letech 1975-1983, který prováděl opět pražský Archeologický ústav, byl logickou součástí dlouhodobého projektu. Ten byl nejprve zaměřen na výzkum raně městské lokality v poloze Hradišt'ko - Sekanka (Richter 1982), ve druhé fázi se rozšířil na lokality ostrovského zázemí (např. Richter 1981) a na vlastní klášter. Cílem bylo provedení srovnávacího výzkumu souborů hmotné kultury kláštera a jeho zázemí a také zpřesnění vývojových fází kláštera, nebot' dosavadní výklad vykazoval jasné mezery. Vedoucím projektu ve všech jeho fázích byl Miroslav Richter, spoluzakladatel české archeologie stř̌edověku, významný český archeolog, dlouholetý ředitel Archeologického ústavu ČSAV. Spolupráce na novém konceptu uměleckohistorického hodnocení lokality a její architektury se ujala Anežka Merhautová-Livorová, přední česká historička umění se zaměřením na raně středověkou architekturu. Jako asistenti výzkumu pracovali Pavel Břicháček a Petr Sommer. První sezony výzkumu byly orientovány na klášterní kostel. Od doby Richterova a Špačkova výzkumu v 60. letech 20. století bylo jasné, že některé koncepty tradičního hodnocení Ostrova je třeba prověřit, a nejsložitější problematiku bylo nutné očekávat právě u kostela. Terénní práce skutečně brzy přinesly nové závažné poznatky, na jejichž základě se ukázalo, že výstavba kostela probíhala přibližně sto let a že byla zahájena po devastujícím požáru klášterních budov v roce 1137. Ty byly tehdy ještě dřevěné - není však také vyloučeno, že se v době požáru už rozbíhaly první kroky výstavby kamenného kostela. Dřevěný klášter byl výzkumem zachycen především ve formě negativních otisků konstrukcí v podobě systému kůlových jam a konstrukcí mezi nimi a vrstvy zuhelnatělého dřeva. Dřevěný kostel byl vybudován $v$ místech pozdějšího románského kamenného chrámu a jeho přesnější podobu se nepodařilo zjistit. Na sever od něj byly umístěny shluky dřevěných objektů, $\mathrm{z}$ nichž některé lze charakterizovat jako polozemnice. Byly aditivně řazeny do prostoru křídel klauzury pozdějšího kamenného kláštera, takže je zřejmé, že již dřevěná podoba kláštera vznikala $\mathrm{v}$ rámci klasického schématu, $\mathrm{v}$ němž konventní kostel tvořil osu klášterního souboru, po jehož severním boku ležela klauzura. Prostorově se obraz „dřevěného“ Ostrova do doby požáru neměnil - např́klad žádný z dřevěných objektů nezasahoval do rajského dvora později respektovaného románskými a gotickými budovami. Již do dřevěného kostela byl pohřben jeden z prvních opatů. Byl uložen do kamenné hrobky, s pastýřskou berlou a v oděvu, 


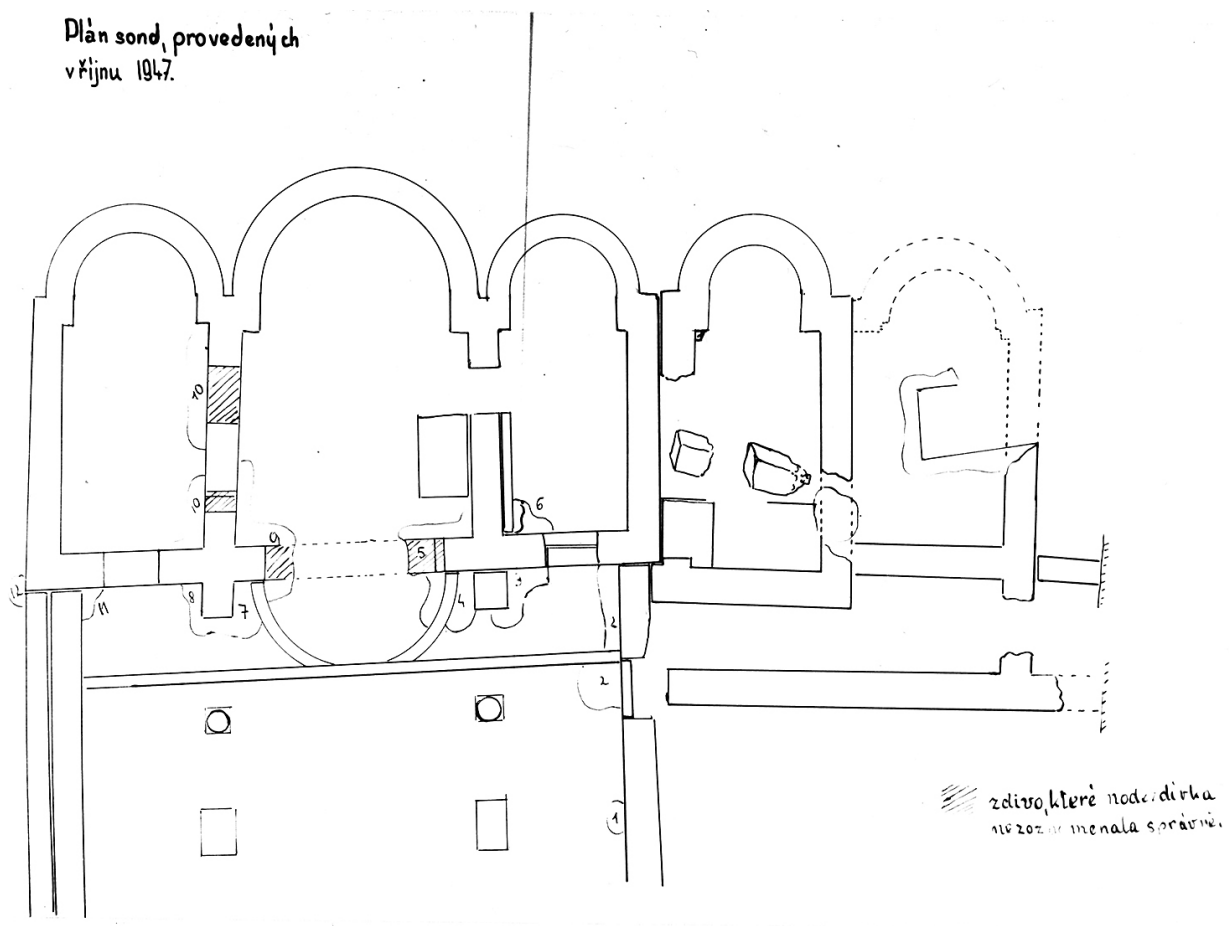

Obr. 7. Plánek sond Františka Stehlíka položených v prostoru baziliky a jižních kaplí. Zdroj archiv ARÚ Praha.

Abb. 7. Planskizze der von František Stehlík im Bereich der Basilika und der südlichen Kapellen gelegten Sondierschnitte. Quelle Archiv des Archäologischen Instituts der Akad. d. Wissenschaften in Prag.
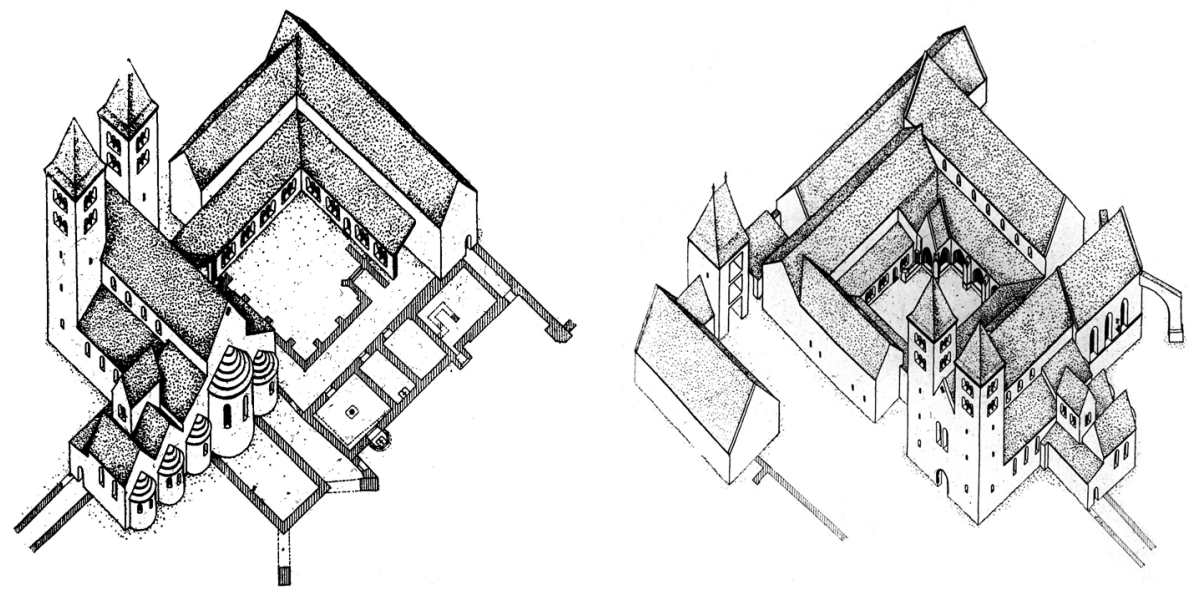

Obr. 8. a 9. Kavalírní rekonstrukční kresby Františka Stehlíka zaměřené na jádro Ostrovského kláštera. První z obrázků akcentuje románské části baziliky a klauzury při pohledu od jihovýchodu, druhý zobrazuje gotické jádro kláštera od jihozápadu. Podle Stehlík 1947, 132, 133.

Abb. 8. und 9. Auf den Kern von Kloster Ostrov ausgerichtete Rekonstruktionszeichnung von František Stehlík in Kavalierprojektion. Die erste Darstellung akzentuiert die romanischen Teile der Basilika und der Klausur aus Südost, die zweite zeigt den gotischen Kern des Klosters aus Südwest. Nach Stehlík 1947, 132, 133. 


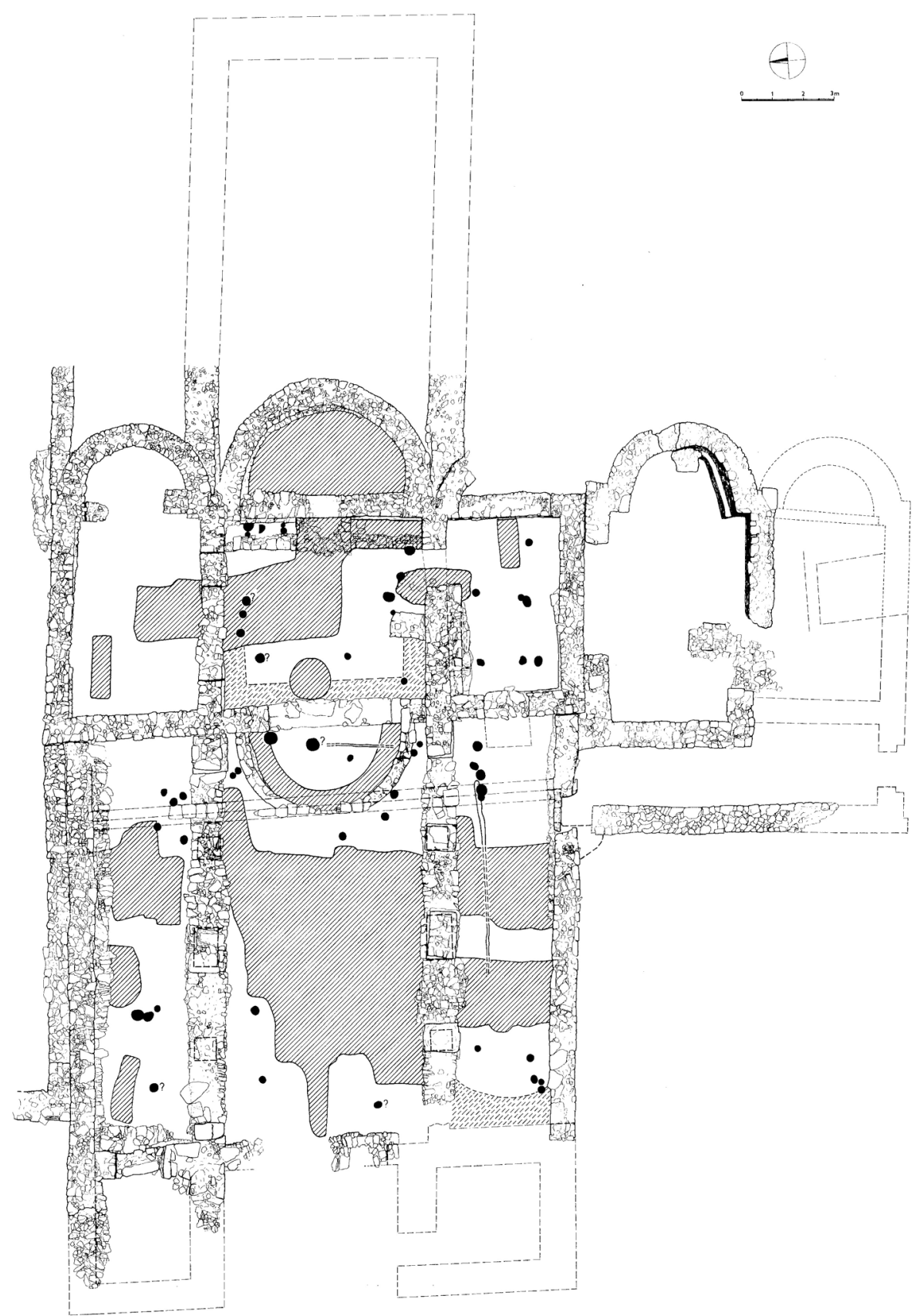

Obr. 10. Výzkum ostrovské baziliky provedený v letech 1975-1983. V rámci chrámového půdorysu jsou přiznány zbytky dřevěných konstrukcí a vrstvy uhlíků z prvního kostela shořelého v roce 1137. Zdroj archiv ARÚ Praha.

Abb. 10. Grabung der Ostrover Basilika in den Jahren 1975-1983. Im Rahmen des Kirchengrundrisses wurden Reste von Holzkonstruktionen und Holzkohleschichten von der ersten, im Jahr 1137 abgebrannten Kirche eingeräumt. Quelle Archiv des Archäologischen Instituts der Akad. d. Wissenschaften in Prag. 
jehož límec byl protkáván zlatými nitkami. Pozoruhodné byly stopy pověrečného jednání, které pohřeb doprovázely. V pánvi mrtvého ležela vaječná skořápka a pazourkové křesadlo. Hrob byl pro klášter velmi významný, takže jej respektovala románská bazilika a jižní křídlo ambitu a po celý středověk byl přístupný k uctívání. Pravděpodobně šlo o další př́íklad významného hrobu uctívaného konventem, který s ním spojoval domácí kult vlastního zakladatele nebo světce in spe v naději na prosazení jeho svatořečení (srov. Vintíř v Břevnově, Prokop v Sázavě, Ludmila u sv. Jiří, Gotšalk nebo Castulus v Želivi; Břicháček-Merhautová-Richter-Sommer 2006).

Po požáru v roce 1137, o němž referují Hradišt’sko-opatovické anály, ihned začala výstavba kamenných budov. Nejprve vznikla trojdílná chórová část baziliky se třemi východními apsidami $\mathrm{v}$ jedné rovině, které na východě uzavíraly prostor vlastního chóru a bočních chórových kaplí. Ve druhé etapě bylo k východnímu chóru přistavěno trojlodí a ve třetí etapě vyrostlo západní dvojvěžové průčelí s hlavním vstupním portálem. Schéma relativní chronologie stavby přinesla archeologie, absolutní datace do něj vložila Anežka Merhautová. Rozborem architektonických zlomků v lapidáriu NM dospěla $\mathrm{k}$ tomu, že trojdílný východní závěr vznikl okolo roku a po roce 1137, trojlodí vyrostlo do roku 1200 a západní dvojvěžové průčelí do roku 1225 (srov. Merhautová-Livorová-Richter-Sršeň 1980, 31-32; Richter-Merhautová-Břicháček-Sommer 1990; obr. 10). Tuto analýzu architektonických detailů doplnila rozborem ostrovských terakot, které zdobily pravděpodobně již dřevěný klášterní kostel, ke klášteru však rozhodně patřily v době románské a gotické (Merhautová 1988). Anežka Merhautová předpokládala, že klášter byl velkým produkčním centrem těchto terakot a že je distribuoval do řady dalších českých lokalit, kde je doložil archeologický nebo stavebně historický výzkum. Tuto hypotézu vyloučila Zuzana Vařilová (2001) rozborem materiálu, z nějž byly dlaždice na jednotlivých lokalitách vyrobeny. Dokázala přitom, že k jejich zhotovení byl vždy použit místní materiál. To však nemění nic na závěrech A. Merhautové, že motivy použité na ostrovských dlaždicích byly přinejmenším z velké části ostrovského původu, ovlivněny knižní malbou. Místní výrobu terakot (ovšem jenom pro potřeby Ostrova) archeologický výzkum potvrdil také. Při výzkumu byla nalezena řada deformovaných terakotových zmetků, které musely vzniknout právě při místní výrobě. O této výrobě svědčí také fakt, že při výzkumu byly nalezeny fragmenty interiérové omítky zdobené otisky modelů, které na Ostrově primárně sloužily při zhotovování kadlubů pro dlaždice (Břicháček-Richter-Sommer 2010; obr. 11).

Ještě v románském interiéru 13. století

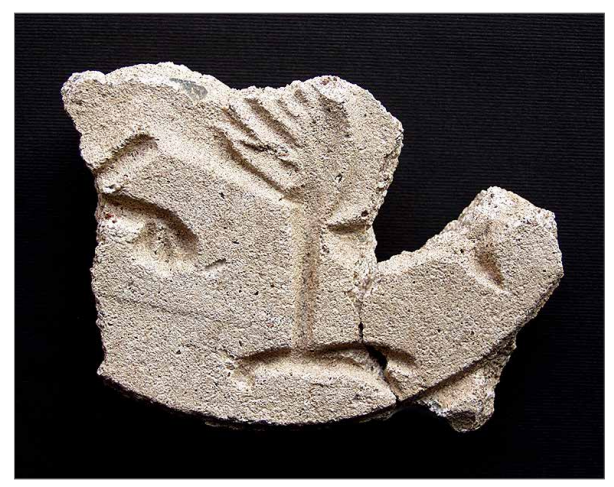

Obr. 11. Otisk modelu pro kadlub ostrovské dlaždice s gryfem nalezený v roce 1975 v severní chórové kapli ostrovské baziliky. Model byl použit atypicky pro otisk v omítce při výzdobě interiéru kaple. Podle Břicháček-RichterSommer 2010, 203-205.

Abb. 11. Abdruck des Modells für eine Matrize einer Ostrover Fliese mit Greif, im Jahr 1975 gefunden in der nördlichen Chorkapelle der Ostrover Basilika. Das Modell wurde atypisch bei der Verzierung des Kapelleninnenraums als Abdruck im Putz verwendet. Nach Břicháček-RichterSommer 2010, 203-205. vznikla před vítězným obloukem půlkruhová přička rozšiřující prostorově stísněný chór směrem do hlavní lodi („,Landův“ plánek půvabně nazývá prostor, který ohrazuje, „zdanlivý prebitár ““"). Po stranách schodiště vedoucího k hlavnímu oltáři vyrostly již zmíněné obdélné schrány na keramické ozvučnice zkoumané M. Richtrem a L. Špačkem v 60. letech. Možná $\mathrm{v}$ téže době nebo o něco později byla $\mathrm{k}$ chóru baziliky přistavěna tzv. první jižní kaple (obr. 12). Výzkumem se podařilo výrazně rozšiŕit argumentaci proti předpokladu Václava Mencla, že kaple je nejstarší kamennou stavbou na Ostrově. Bylo totiž zjištěno, že kaple vůbec neměla severní základ, a že tedy od samotného začátku počítala s oporou sousední baziliky. K ní byl přistavěn další objekt tradičně označovaný jako druhá jižní kaple, který je tedy ještě mladší než první jižní kaple.

Víme již, že severně od baziliky začala vyrůstat románská klauzura, z níž se zachoval 


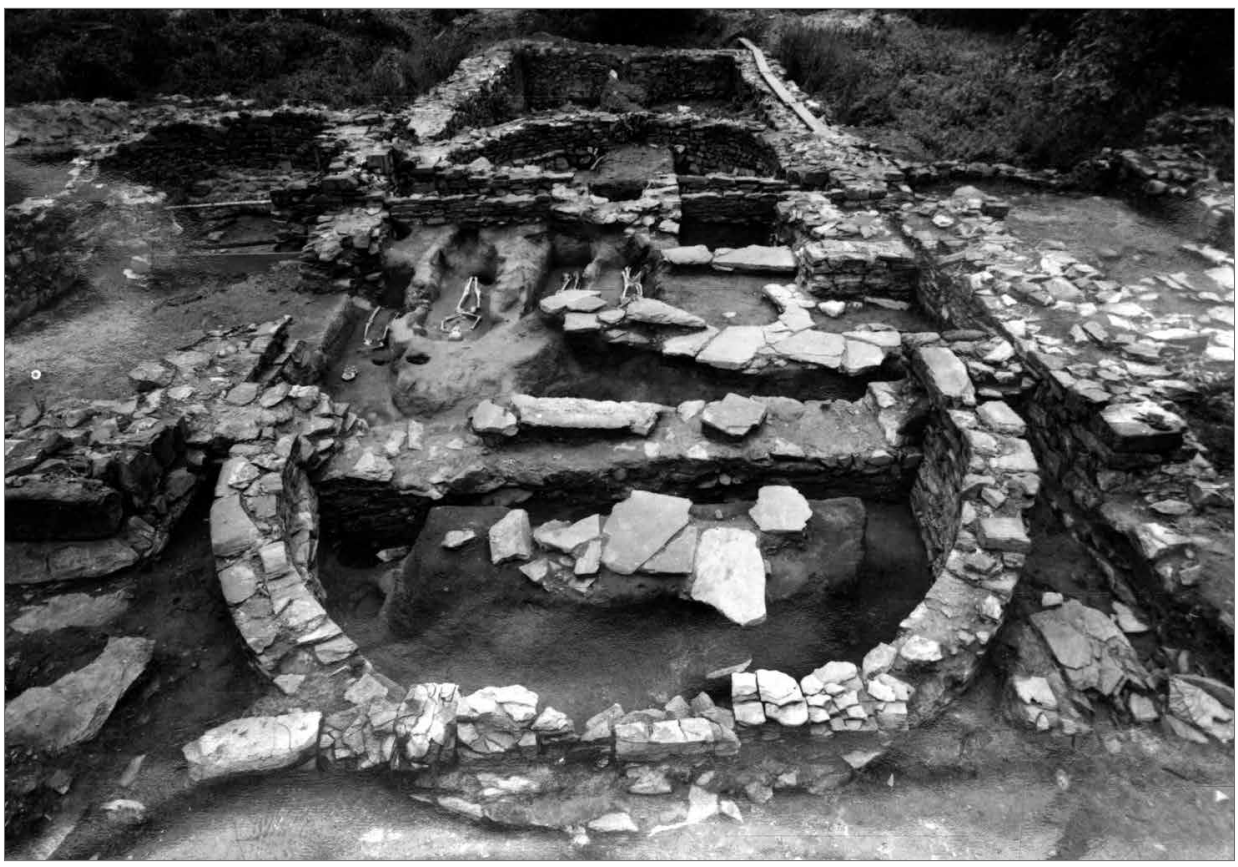

Obr. 12. Ostrovská bazilika po dokončení výzkumu v 70. letech 20. století. Ve středu snímku je chór s bočními kaplemi, v popředí segmentová zed' románského rozšiření chóru do prostoru hlavní lodi, v pozadí se rýsuje zdivo gotického obdélného chóru. Zdroj archiv ARÚ Praha.

Abb. 12. Die Ostrover Basilika nach Grabungsende in den siebziger Jahren des 20. Jahrhunderts. In der Mitte der Aufnahme befindet sich der Chor mit den Seitenkapellen, im Vordergrund die Segmentmauer der romanischen, in den Raum des Hauptschiffes eingreifende Chorerweiterung, im Hintergrund zeichnet sich das Mauerwerk des gotischen Rechteckchors ab. Quelle Archiv des Archäologischen Instituts der Akad. d. Wissenschaften in Prag.

především jižní a západní ambit a západní křídlo. Severní trojtraktové křídlo a východní křídlo klauzury s kapitulní síní je dochováno především v gotické podobě (severní ambit je románský), je ale pravděpodobné, že zde existovaly starší románské objekty. Severní část severního křídla klauzury byla využívána jako hospodářský objekt, jak dokládají zde nalezené sušicí pece. Jedna z nich byla odkryta již Guthovým výzkumem. U severozápadního nároží severního křídla klauzury vznikla ve 13. století brána a naproti ní budova nově interpretovaná jako sídlo opata. $\mathrm{Na}$ jižním konci ostrova vyrostly budovy využívané patrně jako infirmarium (velká halová stavba $\mathrm{s}$ asymetricky umístěnými interiérovými pilíri) a noviciát (?). Lokalizaci infirmaria podporuje nález velkého hřbitova západně od chodby probíhající od budov v jižní části Ostrova okolo obou bočních kaplí k postrannímu vstupu do baziliky. Ostrovská pohřebiště jsou zdrojem řady dalších informací. Hřbitov jižně od baziliky byl v areálu kláštera největší, ale řada hrobů byla nalezena tradičně v sakrálních objektech kláštera, zejména $\mathrm{v}$ ambitech. Výjimku představuje první jižní kaple, což vedlo k hypotéze, že jde o kapli speciálního účelu, jenž vysvětluje její propojení s infirmariem. Kaple infirmaria (s emporou představeného infirmaria) je dobrým možným vysvětlením, které podporuje nález fragmentu transenny, učiněný v době Guthova výzkumu. Transenna umožňující akustickou - nikoliv fyzickou - účast na bohoslužbách k výbavě kaple pro nemocné patří (Sommer 1994).

Románský areál kláštera byl roku 1278 vypleněn Branibory. K definitivní nápravě škod došlo v době vlády Karla IV., kdy byl vybudován nový velký obdélný chór, jehož severo- a jihozápadní nároží zvnějšku vzpíraly dva opěrné oblouky. Chór nahradil starou hlavní románskou apsidu. Ta byla zbořena, částečně prolomena, stejně jako oblá příčka u vítězného oblouku, na 


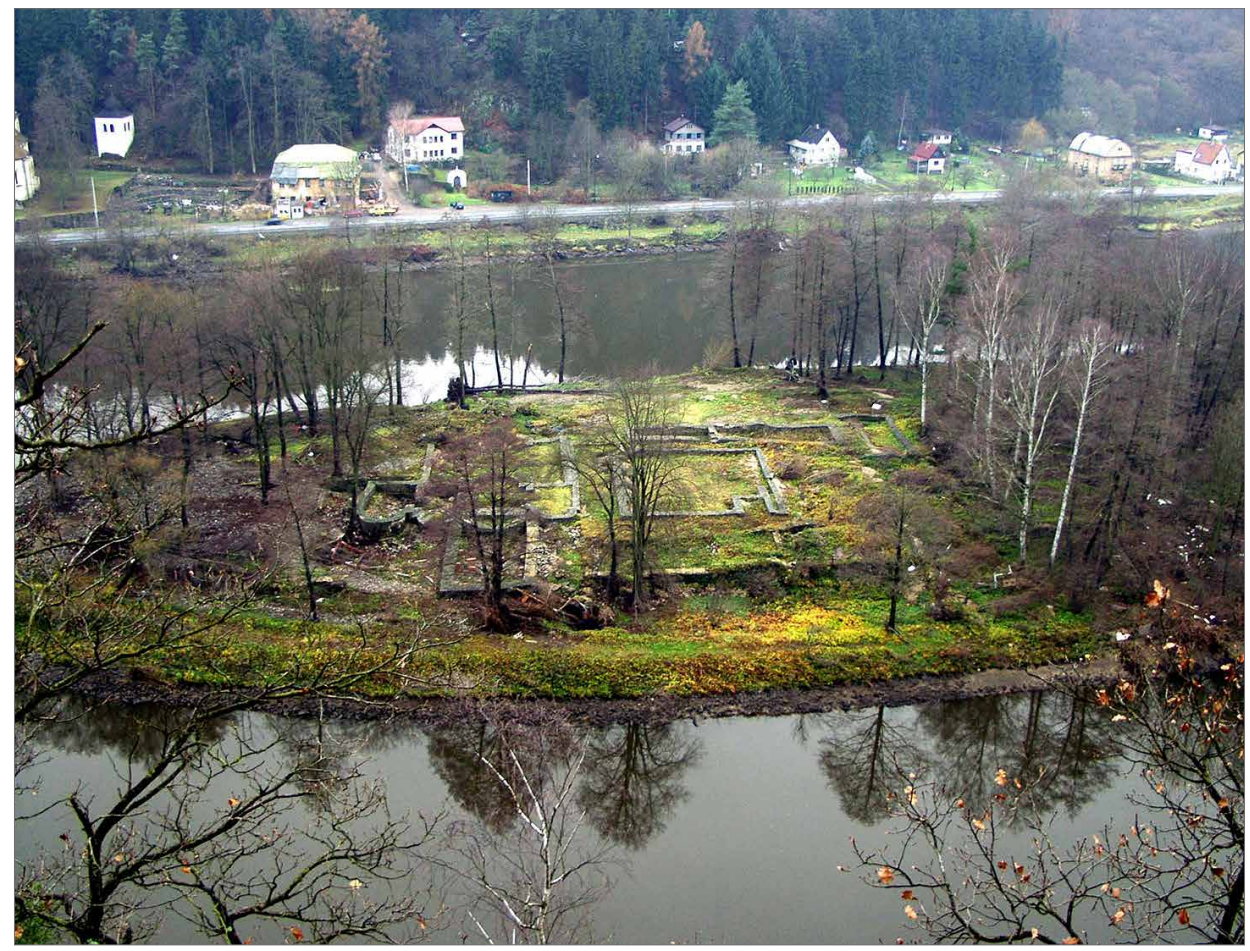

Obr. 13. Dnešní stav Ostrovského kláštera dokumentovaný z př̌ibližně stejného stanoviště na Hradišt’ku - Sekance, jaké zaujal autor obr. 6 na konci výzkumu roku 1934. Foto Petr Sommer.

Abb. 13. Heutiger Zustand von Kloster Ostrov, dokumentiert vom ungefähr gleichen Standort, den der Autor von Abb. 6 am Ende der Grabung von 1934 in der Lage Hradišt'ko - Sekanka eingenommen hatte. Foto Petr Sommer.

jejíž korunu byly uloženy stupně vedoucí do nového chóru. V téže době vyrostly také nové, gotické části klauzury. Šlo zejména o východní křídlo s kapitulní síní a o severní křídlo, v němž zůstal zachován románský ambit. V prostoru rajského dvora (v jeho severovýchodním koutě) vzniklo gotické lavatorium, to bylo již v pořadí čtvrtou stavbou tohoto účelu, jejíž dva (?) románské předchůdce výzkum odkryl u západní vnitřní zdi východního ambitu. Jejich existence je dalším argumentem pro románského předchůdce gotického východního křídla klauzury (není ostatně logické, že by románský klášter vznikl bez východního kř́ídla s kapitulní síní, eventuálně se společnou pracovní mniškou místností a s dormitářem v prvním patře). Pokud jde o zásobování vodou - při výzkumu byla v severozápadním sektoru rajského dvora nalezena studna, jejíž kamenné roubení bylo původně spojeno krytým kamenným kanálkem s místností v severní části západního kř́ídla klauzury. Je velmi pravděpodobné, že tato místnost byla kuchyní, místnost od ní na jih mohla sloužit jako cellarium, kdežto v severním rameni klauzury lze předpokládat refektář. Lokalizace cellaria a refektáře je samozřejmě hypotetická, ale založená na logice schématu benediktinské klauzury, v níž všechny tři jednotky spolu provozně souvisejí.

Výzkum let 1975-1983 významně rozšiřil znalosti ostrovského stavebního schématu získané při předchozích výzkumech. Jako vždy však zůstala řada otázek otevřena. Nebylo možné například zkoumat východní kř́ídlo klauzury, funkčně neznámá zůstává severní část kláštera, v níž předpokládáme hospodářské a výrobní provozy. Zde by např́íklad mohly být situovány dílny, v nichž vznikaly terakotové dlaždice a obkládací desky, které románský a gotický Ostrov významně ilustrují a charakterizují. 


\section{Výsledky archeologického výzkumu Ostrovského kláštera a jeho postavení v rámci české archeologie středověku}

Ohlédneme-li se po více než stu letech archeologického výzkumu Ostrovského kláštera, na němž se od roku 1925 zásadním způsobem podílel Státní archeologický ústav a později Archeologický ústav ČSAV (dnes AV ČR), můžeme konstatovat, že jde o výzkum, který charakterizuje jak vývoj oboru české archeologie středověku, tak Archeologického ústavu samotného. Na začátku se setkáváme s formou archeologických akcí, které jsou nástrojem k nalézání artefaktů, jež oceňuje zejména dějepis umění a muzeologie. Bylo to zcela v souladu s dobovými názory na to, že archeologie je pomocná věda dějin umění, která nemá používat jemnou prehistorickou metodu výzkumu, protože ta je pro účely dějin umění zbytečně náročná (Mencl 1942). Archeologie však i na Ostrově procházela vývojem, jenž vedl k medievistické disciplíně, která k poznávání středověku přispívá vlastními metodami, nástroji, prameny a vlastním kladením otázek. Pokud jde o české prostředí, zdůrazňoval Zdeněk Smetánka, že místo na této cestě, během níž se začínal měnit archeologický servis ve vědecký výzkum, leží na Pražském hradě, kde byla archeologickými argumenty opravena uměleckohistorická datace tzv. trezoru, sklepa u jižní stěny svatováclavské kaple. Sklep nalezl Kamil Hilbert v roce 1911 a vysvětlil jej jako stavbu 14. století. Po dvaceti letech toto datování a vysvětlení změnil Karel Guth na základě stratigrafických pozorování vztahů vrstev a architektury (Guth 1934, 748, pozn. 211). I na dnes aktuálním konci tohoto vývoje je však třeba jedním dechem dodat, že každá medievistická disciplína je povinna kontrolovat své poznání s výsledky a kritikou disciplín dalších a spolupracovat s nimi, abychom se alespoň po krůčcích blížili kýžené totální historii Fernanda Braudela (a jak vždycky dodával prof. Jaromír Homolka - také Wilhelma Vögeho, čímž připomínal nutnost zapojení také dějin umění do konceptu totální historie). Archeologický ústav se na tomto oborovém precizování významně podílel. Zejména v době po druhé světové válce se v jeho rámci setkáváme se stále složitějším promýšlením výzkumných témat a s jejich provazováním s dalšími obory v široké medievistické, ale i třeba přírodovědecké kooperaci. Poznávání kláštera na Ostrově u Davle je toho dobrou ilustrací. Cesta k moderní výzkumné metodě není samozřejmě cestou jenom Archeologického ústavu. Ten se na ní pohybuje v interakcích s řadou dalších institucí. V souvislosti s Ostrovským klášterem na ní zaujímají čestná místa jak otcové oboru, tak historik umění kladoucí si otázky po stratigrafii staveb, tak lidé archeologie středověku kladoucí si otázky kauzálních vazeb mezi výpovědí velkého spektra vědních oborů. Je samozřejmě přitom všem třeba, abychom si byli vědomi skutečnosti, že adjektivum „,moderní“ je odvozeno od latinského modernus, což znamená „,nedávný, nový“. To, co je moderní, se tedy neustále posouvá v čase.

Z ostrovských výzkumů vyplývá ještě jedna významná zkušenost, která se samozřejmě opakuje na řadě dalších lokalit. Odkrytá zdiva, která jsou prezentována v rámci památkové úpravy a prezentace jakékoliv lokality, jsou bez pravidelné údržby a konzervace odsouzena k zániku. Stačí, porovnáme-li stav ostrovských ruin ve 30 . letech a v 80 . letech 20 . století. Nedostatečná údržba a časté vltavské povodně způsobily obrovský úbytek zdejších středověkých konstrukcí. Po ukončení výzkumu v 80. letech 20. století nastoupila na Ostrově rozsáhlá památková úprava. Originální zdiva byla většinou zcela zasypána a nad terén vyčnívaly jenom nové nadezdívky viditelně oddělené od originálu. Přes tuto péči poničila velká povodeň roku 2002 jak nadezdívky, tak místy i originální zdiva a dodnes nedošlo k nápravě. Mezi velké zodpovědnosti každého archeologa tak patří nejenom co nejúplnější a nejdokonalejší výzkumný proces, ale i budoucnost lokality poté, co ji opustí.

Tento článek vznikl při řešení projektu „Sázava - archeologie benediktinského kláštera“ (19-17636S) podporovaného GAČR. 


\section{Literatura}

Almanach X: Výroční zpráva o stavu a činnosti České Akademie od 2. prosince 1898 do 2. prosince 1899, Almanach České akademie věd a umění X, 1900, 115-116.

Almanach XI: Výroční zpráva o stavu a činnosti České Akademie od 2. prosince 1899 do 2. prosince 1900, Almanach České akademie věd a umění XI, 1901, 123.

Biografický slovník českých zemí: Dostupné z: http://biography.hiu.cas.cz/Personal/index.php/ FABIAN_V\%C3\%A1clav_11.6.1877-30.9.1931.

BŘICHÁČEK, P.-MERHAUTOVÁ, A.-RICHTER, M.-SOMMER, P., 2006: Opatský hrob z doby počátků Ostrova u Davle, Archaeologica Pragensia 18, 45-64.

BŘICHÁČEK, P.-RICHTER, M.-SOMMER, P., 2003: Archeologie k miléniu ostrovského kláštera. In: 1000 let kláštera na Ostrově (999-1999) (Stehlíková, D.-Brych, V., edd.), 13-28. Praha.

- 2010: Neobvyklý prvek interiérové výzdoby románské baziliky na Ostrově u Davle. In: Čechy jsou plné kostelů - Bohemia plena est ecclesiis. Kniha k poctě PhDr. Anežky Merhautové, DrSc. (Studničková, M., ed.), 199-207. Praha.

DROBNÁ, Z., 1958: Lapidarium Národního musea. In: Lapidarium Národního musea. Sbírka české architektonické plastiky XI. až XIX. století, 7-27. Praha.

FABIAN, V., 1910-1912: O vzniku lapidária muzejního, PA XXIV, 169-178.

FILIP, J., 1966: Enzyklopädisches Handuch zur Ur- und Frühgeschichte Europas I. Praha.

GUTH, K., 1934: Praha, Budeč, Boleslav. In: Svatováclavský sborník vydaný na památku 1000. výročí smrti knížete Václava svatého I, 686-818. Praha.

- 1937: Ostrovský klášter. In: Ottův slovník naučný nové doby IV/2, 801. Praha.

HLUBINKA, R., 1933: Výzkum zbytků benediktinského kláštera na Ostrově u Davle, Za starou Prahu 17, č. $1,2-4$.

KVĚT, J., 1946: Karel Guth - nekrolog, PA XLII, 141-143.

LEHNER, F., J., 1905: Dějiny umění národa českého I. Doba románská, svazek II. Architektura, část II. Praha.

MENCL, V., 1942: O methodice středověkých výkopů, ZPP 6, sešit 2, 6-8; sešit 3, 17-23; sešit 3, 33-37.

- 1959: Architektura předrománských Čech, Umění VII, 331-353.

MERHAUTOVÁ, A., 1988: Skromné umění. Ostrovská zdobená terakota. Praha.

MERHAUTOVÁ-LIVOROVÁ, A.-RICHTER, M.-SRŠEŇ, L., 1980: Architektonické zlomky ostrovského kláštera, SbNM A XXXIV, 1-105.

PÁCAL, M., 2007: Zapomenutý fantom. Život a dílo architekta a malíře Františka Xavera Margolda. Chotěšov.

RICHTER, M., 1981: Zaniklá hornická osada u Klínce, Praehistorica VIII, Varia archaeologica 2, 301-306.

- 1982: Hradišt'ko u Davle, městečko Ostrovského kláštera. Praha.

RICHTER, M.-MERHAUTOVÁ, A.-BŘICHÁČEK, P.-SOMMER, P., 1990: Bazilika s první jižní kaplí ostrovského kláštera, Umění XXXVIII, 185-195.

SKLENÁŘ, K., 2013: Archeolog Josef Ladislav Píč jako muzejník v Národním muzeu, ČNM A 183, 54-102.

SKLENÁŘ, K.-SKLENÁŘOVÁ, Z., 2005: Biografický slovník českých, moravských a slezských archeologů. Praha.

SOMMER, P., 1994: Die Seitenkapelle der romanischen Basilika in Ostrov bei Davle, PA LXXXV, 81-106.

STEHLÍKOVÁ, D., 2003: Ostrovské náhrobky a pečeti z let 1220-1520. In: 1000 let kláštera na Ostrově (999-1999) (Stehlíková, D.-Brych, V., edd.), 75-102. Praha.

- 2014: Korpus Ukřižovaného Krista z Ostrova. In: Otevři zahradu rajskou. Benediktini v srdci Evropy 800-1300 (Foltýn, D.-Klípa, J.-Mašková, P.-Sommer, P.-Vlnas, V., edd.), 153. Praha.

ŠPAČEK, L., 1963: Akustická nádoba z Ostrovského kláštera, ČNM oddíl věd společenských 132, 137-142. - 1967: Archeologický výzkum ostrovského kláštera v 1. 1962-1964, AR XIX, 43-54.

UHLÍKOVÁ, K., 2013: Hlubinka, Rudolf. In: Biografický slovník památkové péče. Dostupné z: https://web. archive.org/web/20140202093631/http://www.npu.cz/biograficky-slovnik-pamatkaru-I/hlubinka-rudolf/. VAŘILOVÁ, Z., 2001: Surovinové zdroje a provenience románských terakotových dlaždic, AR LIII, 515-563. 
VAVROUŠEK, B., 1938: Literární atlas československý 2. Praha.

WIRTH, Z., 1984: Rudolf Hlubinka - sedmdesátníkem, Za starou Prahu 23, 4, 5-6.

WOCEL, J. E., 1855: Byzantinský krucifix, nalezený v rumech kláštera Ostrovského, Památky archaeologické a místopisné I, 136-140, obr. 9.

\section{Zusammenfassung}

\section{Ein Jahrhundert archäologische Grabungen von Kloster Ostrov (Katastergebiet Davle)}

Das zweitälteste benediktinische Männerkloster in Böhmen wurde in der Zeit um das Jahr 1000 auf einer Moldauinsel in der Nähe des Zusammenflusses der Flüsse Moldau und Sasau gegründet. Von den Hussitenkriegen wurde es zerstört und im Jahr 1517 definitiv verlassen. Im Jahr 1799 wurde an der Klosterstätte ein Limogeser Korpus von Christus gefunden, der ein romantisches denkmalpflegerisches und museales Interesse an dieser Fundstelle weckte. Ende des 19. Jahrhunderts erfolgte dort die erste archäologische Grabung (B. Matějka), deren Ergebnis die Kenntnis der Grundform der Mitte des Klosterschemas war. Die darauffolgende Grabung erfolgte im Jahr 1907 (V. Fabián) und brachte eine Reihe von Teilerkenntnissen über die seit Ende des 19. Jahrhunderts bekannten Situationen. Diese zwei Grabungen wurden vom Prager Nationalmuseum durchgeführt. An sie schlossen eine Test- und Rettungsgrabung des im Jahr 1919 gegründeten Staatlichen archäologischen Instituts an. In den Jahren 1925 (J. Böhm) und 1933-1934 (K. Guth) erfolgten dort große Grabungen, deren Ziel es war, die Orientierung in der untergegangenen Klosterbebauung so gut wie möglich zu präzisieren und den Raum zu definieren, der bei der Durchführung des Bauprojektes der nahegelegenen Talsperre in Vrané geschützt werden muss. Das ursprüngliche Konzept des Projektes sah vor, den Wasserstand der Moldau soweit zu erhöhen, dass die ganze Fundstelle unter Wasser verschwinden würde. Die umfangreichen Freilegungen der dreißiger Jahre lieferten indes grundlegende Ergänzungen der Erkenntnisse über die Disposition der romanischen und gotischen Gebäude, und das Projekt Talsperre wurde so umgearbeitet, dass der wichtigste Teil des Grundrisses über Wasser blieb. Weitere Grabungen der Jahre 1947 (F. Stehlík), 1962-1964 (M. Richter, L. Špaček) und 1975-1983 (M. Richter, A. Merhautová) waren auf eine detaillierte Erfassung der Fundstelle und auf die Chronologie der dortigen Objekte ausgerichtet.

Ergebnis dessen ist ein großer Komplex an Kenntnissen und Quellen, die darüber Auskunft geben, dass die ersten Bauten auf der Insel Ostrov aus Holz entstanden. Die einzelnen Objekte waren damals bereits nach einem Schema geordnet, in dessen Zentrum die Kirche stand, entlang deren Nordseite die Klausur emporwuchs. Das Holzkloster brannte im Jahr $1137 \mathrm{ab}$, und an seiner Stelle begannen die ersten Steingebäude emporzuwachsen. Um das Jahr des Brandes oder direkt nach ihm wurde der dreiteilige Abschluss der Basilika mit drei Apsiden in der selben Ebene errichtet. Bis Ende des 12. Jahrhunderts wuchs ein basilikales dreischiffiges Langhaus mit rheinischem Stützenwechsel empor. In der Zeit um das Jahr 1225 entstand die zweitürmige Westfassade der Basilika. Um Mitte des 13. Jahrhunderts und kurz danach entstanden südlich von der südlichen Chorkapelle zwei weitere Kapellen, von denen die sog. erste Südkapelle offenbar mit dem Betrieb eines Infirmariums zusammenhing, das (ebenso wie das Noviziat) im südlichen Teil von Ostrov angenommen werden kann. Im Rahmen des gotischen Umbaus der Basilika wuchs ein neuer Rechteckchor empor, der mit dem alten Chor der Basilika durch einen Durchbruch der alten Hauptapsis verbunden wurde. Der ursprüngliche Chor wurde höher gelegt und mit dem Hauptchor durch neue Steintreppen verbunden wurde. Nördlich von der Basilika wurde um den Klosterhof eine Klausur mit Kreuzgang errichtet. Der nördliche und westliche Arm der Klausur ist romanisch, der südliche und östliche ist - offenbar an den Stellen der älteren romanischen Vorgänger - gotisch. Der nördliche Arm der Klausur ist atypisch dreitraktig. Nördlich vom Kreuzgang wuchs wahrscheinlich das Refektorium empor, an dessen Nordseite 
der Wirtschaftsflügel anschloss. Seine Funktion wird durch Funde von unterirdischen Trockenöfen belegt. Westlich vom Nordflügel der Klausur stand die Eingangspforte, an die von Westen her ein Gebäude, wahrscheinlich die Prälatur, anschloss. Noch weiter nach Norden wurden die Fundamente von Objekten entdeckt, deren Zweck unklar ist. Es ist wahrscheinlich, dass es sich bei ihnen wieder um Wirtschafts- und Produktionsgebäude handelte. Dort kann man etwa eine Werkstatt erwarten, in der die bekannten Ostrover Terrakotten (reliefverzierte Fußbodenfliesen und Innenraumverkleidungsplatten des 12.-14. Jahrhunderts) hergestellt wurden. Andere archäologische Unternehmungen (M. Richter) verfolgten eine Grabung im Ostrover Hinterland. Die in diesem Zusammenhang bedeutendste Unternehmung war die Grabung an einer mittelalterlichen Siedlungswüstung frühstädtischen Typs aus der zweiten Hälfte des 13. Jahrhunderts in der Lage Hradišt'ko - Sekanka.

Der vorliegende Beitrag entstand während der Durchführung des von der Grantagentur der ČR (19-17636S) geförderten Projektes „Sasau - Archäologie eines Benediktinerklosters“.

prof. PhDr. Petr Sommer, CSc., DSc., Archeologický ústav AV ČR Praha, v. v. i., Letenská 4, 11801 Praha, Česká republika,sommer@arup.cas.cz 
